- уміння вчителя змінити план уроку, якщо цього вимагає конкретна ситуація;

- використання різноманітних форм уроків: урок-концерт, урок-психодрама, урок-фантазія.

Аналіз спостережень дозволяє говорити про те, що за створення вказаних умов для занять підлітки у змозі за короткий проміжок часу почати емоційно відгукуватися на художньо повноцінну музику, навчитися відкривати для себе емоційну виразність музичного твору, усвідомлювати емоційне співпереживання.

Проведена робота доводить важливість цілеспрямованих музичних занять для оздоровлення емоційної сфери девіантних підлітків, збагачення їхньої духовного світу.

\title{
Література
}

1. Абдуллин Э. Б. Методологическая культура педагога-музыканта [учеб. пособ. для студ. высших учеб. заведений] / Э. Б. Абдуллин. - М.: Изд. центр «Академия», 2002. - 272 с. 2. Баранов В. В. Дослідження автобіографії девіантного підлітка як один з прийомів виявлення його десоціалізації / В. В. Баранов, І. О. Похлебна // Практична психологія і соціальна робота. - 2001. - № 9. 3. Денисов І. Г. Біологічні чинники девіантної поведінки та профілактика їх виявлень у вихованні громадської спрямованості у підлітковому віці / І. Г. Денисов // Постметодика. - 2002. - №7-8 (4546). - С. 207-212. 4. Клейберг Ю. А. Психология девиантного поведения / Ю. А. Клейберг. - М., 2001. - 454 с. 5. Змановская Е. В. Девиантология: психология отклоняющегося поведения: [учеб. пособ. для студ. высш. учеб. заведений] / Е. В. Змановская. - М. : Изд. Центр «Академия», 2003. 288 с. 6. Оржеховська В. М. Профілактика правопорушень серед неповнолітніх: [навч.-метод. посіб.] / В.М. Оржеховська. - К.: КВІАН, 1996. -352 с.

УДК 373.5.016:91

Світлана Тросюк

\section{КОМПЕТЕНТНІСНИЙ ПІДХІД У НАВЧАННІ ГЕОГРАФІЇ УЧНІВ ОСНОВНОЇ ШКОЛИ}

Тросюк С. Д. Компетентнісний підхід у навчанні географії учнів основної школи.

У статті розкрито сутнісні характеристики компетентнісного підходу у навчанні географії учнів основної школи. Подано вичерпну характеристику географічних компетентностей учнів основної школи у процесі вивчення географії. Розкрито взаємозв'язок міри упровадження компетентнісного підходу у навчанні географії учнів основної школи і рівнями сформованості географічних компетентностей у процесі вивчення навчальних предметів природничого циклу.

Ключові слова: компетентнісний підхід, учні основної школи, навчання географії в основній школі, географічні компетентності.

Тросюк С. Д. Компетентностній поход в обучении географии учащихся основной школы.

В статье раскрыты сущностные характеристики компетентностного подхода в обучении географии учеников основной школы. Приведена исчерпывающая характеристика географических компетентностей учеников основной школы в процессе изучения географии. Раскрыта взаимосвязь степени реализации компетентностного подхода в обучении географии учеников основной школы и уровнями сформированости географических компетеностей в процессе изучения учебных предметов природоведческого цикла.

Ключевые слова: компетеностный подход, ученики основной школы, обучение географии в основной школе, географические компетености.

Trosyuk S. D. Competence approach in teaching of geography primary school students.

The article reveals the essential characteristics of competence-based approach in teaching students the basic geography of the school. Given an exhaustive description of geographical competences elementary school students in the study of geography. A reconciliation of the degree of implementation kompetenostnogo approach to learning geography primary school pupils and level of development of geographic competence in the study of academic subjects Natural History cycle.

Key words: competence approach, primary school pupils, teaching geography in elementary school, geographic competence.

Нині в теорії вітчизняної географічної науки та теорії соціальної географії відбувається перегляд і переосмислення змісту, форм, методів і принципів розроблення нових підходів до формування географічних компетентностей. Цей процес зумовлює необхідність у створенні 
науково-методичних праць, в основу яких покладено галузеву диференціацію теоретикометодичних досліджень, присвячених формуванню або географічних, або економічних знань. Уважаємо, що зміст географічної освіти 3 навчальних предметів, зокрема географії й економіки, у Державному стандарті середньої освіти належить до різних освітніх галузей («Природознавства» і «Суспільствознавства» відповідно), і це може призвести до втрати цілісного сприйняття навколишнього середовища й господарської діяльності людини в процесі іiї навчання та життедіяльності.

Загальні аспекти ключових компетентностей знайшли послідовне висвітлення в роботах А. Вербицького, П. Горностая, В. Донія, I. Срмакова, I. Зимньої, В. Ляшенка, Г. Несен, О. Овчарук, О. Савченко, В. Сєрікова, Л.Сохань та інших.

Проблеми вдосконалення змісту й методики навчання географії та економіки на сучасному етапі досліджували вітчизняні науковці М. Багров, М. Баранський, Н. Бірюкова, Л.Булава, Й. Гілецький, Ф. Заставний, С. Коберник, В. Корнєєв, М. Криловець, Л. Круглик, П. Масляк, Т. Назаренко, Я. Олійник, М. Паламарчук, М. Пістун, А. Сиротенко, О. Топузов, О. Топчієв, Б. Яценко та інші.

Компетентнісний підхід в освіті безпосередньо пов'язано з ідеєю цілеспрямованості та цілезаданості навчально-виховного процесу, з формуванням у педагогів професійної компетентності.

Компетентнісний підхід грунтується на двох базових поняттях: компетенція та компетентність. Необхідно зазначити, що понятійний апарат, який характеризує смисл компетентнісного підходу в освіті, трактується залежно від співвідношення цих понять. Серед науковців немає єдиної думки щодо трактування значення цих термінів (деякі дослідники використовують поняття «компетенція» і «компетентність» як синоніми, але сьогодні більшість чітко їх розрізняє), визначення їх складників (наприклад, визначають від 3 до 37 видів компетентностей і компетенцій). Водночас науковці, які досліджували природу компетентності та компетенції, вказують на їх різнобічний, багатоаспектний та системний характер.

А. Хуторський із позицій особистісно зорієнтованого навчання вважає, що компетенція це сукупність взаємозв'язаних якостей особистості (знань, умінь, навичок, способів діяльності), які задаються до певного кола предметів і процесів, необхідних для того, щоб продуктивно діяти стосовно них, тобто це сукупність смислових орієнтацій, які необхідні для продуктивної діяльності; компетентність - володіння людиною відповідною компетенцією, яка передбачає особистісне ставлення до неї та до предмета діяльності [2, с.60]. Як окрему структуру дослідник виокремлює освітню компетенцію, визначаючи ії як сукупність взаємозв'язаних смислових орієнтацій, знань, умінь, навичок і досвіду діяльності учня, які необхідні для того, щоб здійснювати особистісно та соціально значущу продуктивну діяльність щодо об'єктів реальної дійсності [183, с. 62].

Культурологічний підxід в освіті, пов'язаний з ідеєю створення умов для розвитку мислення, що «породжує» (М. Мамардашвілі), збагатив творчим змістом концепції компетентнісного підходу, де компетентність розуміється як творча реалізація внутрішньо утвореної цілісної структури діяльності на підгрунті наявних знань, умінь і навичок, отриманих у процесі навчання. У цьому випадку процес формування компетентності, в тому числі й інформаційної, пов'язується з організацією навчально-пізнавальної діяльності як культуровідповідної, у процесі якого створюються можливості виходу за межі заданої ситуації, де й відбувається розвиток мислення, що «породжує», і накопичення творчого потенціалу особистості.

Дж. Равен визначає компетентність як специфічну здатність, яка є необхідною для ефективного здійснення конкретної дії в конкретній предметній галузі та яка передбачає вузькоспеціальні знання, особливі предметні навички, способи мислення, а також розуміння відповідальності за свої дії [1, с. 6].

У різних дослідженнях компетентність розглядається як системна єдність, що інтегрує особистісні, предметні та інструментальні особливості та компоненти; вона не є простим володінням знаннями, а є постійним прагненням до їх оновлення та використання в конкретних умовах, тобто володіння мобільними й оперативними знаннями; це гнучкість і критичність мислення, тобто здатність до вибору найбільш оптимальних та ефективних рішень і відкидання помилкових, хибних; це знання, уміння, навички здійснення діяльності (Н.Тализіна).

Отже, компетентність - це спосіб існування знань, умінь, освіченості, що сприяє особистісній самореалізації, знаходженню тому, хто навчається, свого місця в світі, внаслідок чого 
освіта стає високо мотивованою, особисто орієнтованою, забезпечує необхідність особистісного потенціалу, визнання особистості оточуючими та усвідомлення нею своєї значущості.

Отже, компетентнісний підхід в освіті безпосередньо пов'язано з ідеєю цілеспрямованості та цілезаданості навчально-виховного процесу. Компетенція - це соціальна вимога (норма), яка $€$ заданою наперед, до освітньої підготовки фахівця, й є необхідною для його якісної продуктивної діяльності у відповідній галузі, а компетентність - комплексна інтегративна характеристика особистості (С.Трішина, А.Хуторськой). Також багатьма дослідниками компетентність розглядається як уміння актуалізувати накопичені знання та вміння, коли це необхідно, тобто наявна особистісна якість (сукупність якостей) особистості та мінімально необхідний досвід діяльності у заданій галузі. Компетентність виявляється та здобувається в діяльності.

Проективно до розглядуваного в дослідженні поняття географічної компентності учнів совноної можемо зробити такі узагальнення:

1. Категорія «компетентність» невідривно пов'язана 3 феноменом «культура», $\epsilon$ результатом розвитку особистості, iï освіченості та вихованості Загальнокультурна компетенція є сукупністю трьох аспектів: смислового (адекватність осмислення ситуації в культурному контексті); проблемно-практичного (адекватність розпізнавання ситуації, адекватна постановка питання та ефективне виконання цілей, завдань, норм у певних обставинах); комунікативного (адекватне спілкування в ситуаціях культурного контексту та відповідно до культурних зразків спілкування та взаємодії). Отже, предметна компетентність $\epsilon$ похідним компонентом загальнокультурної компетентності кожної людини.

2. Компетентність як система якостей та умінь, що уможливлює ефективне використання в реальній освітній практиці певного набору знань, умінь $і$ навичок.

3. Компетентність як система взаємопов'язаних компетенцій. А.Хуторський пропонує трирівневу ієрархію компетенцій (ключові, загальнопредметні, предметні) та визначає перелік освітніх компетенцій (ціннісно-смислова, загальнокультурна, навчально-пізнавальна, інформаційна, комунікативна, соціально-трудова, особистісного вдосконалення), які залежать від цілей загальної освіти, структурної презентації соціального досвіду та досвіду особистості учня основної школи, який дозволяє йому оволодіти соціальним (соціально-економічним) досвідом, отримати навички життя і практичної діяльності в суспільстві [2, с. 63].

Розглянемо систему ключових освітніх компетенцій більш детально.

Географічна компетентність як педагогічна категорія містить узагальнено компетентності, на грунті яких мають розроблятися компоненти (якості) особистісного утворення:

1. Ціннісно-смислова компетентність - це компетенція, корелятивна до світоглядної пов'язана з ціннісними уявленнями учня, його здатністю бачити та розуміти навколишній світ, орієнтуватися в ньому, усвідомлювати свою роль і призначення, вміти обирати цільові й смислові установлення для своїх дій і вчинків, приймати рішення. Ця компетенція забезпечує механізм самовизначення учня в ситуаціях навчальної або іншої діяльності. Саме від цієї компетенції залежить індивідуальна освітня траєкторія учня і програма його життєдіяльності загалом.

2. Загальнокультурна компетенція - коло питань, у яких учень повинен бути добре обізнаним, мати знання та досвід діяльності. Це особливості національної та загальнолюдської культури, духовно-моральні основи життя людини і людства, окремих народів, культурологічні засади родинних, соціальних, суспільних явищ і традицій, роль науки і релігії в житті людини, їх вплив на світ, компетенції у сферах побуту та культурному дозвіллі (наприклад, володіння ефективними способами організації вільного часу).

Зауважимо, що загальнокультурна компетентність органічно поєднує географічний i країнознавчий параметри:

\section{«Культура й соціальний розвиток країн Європи» НІМЕЧЧИНА}

У системі освіти обвязковою є десятирічна освіта. Функціонує система вищих навчальних закладів. Існує розгалужена мережа університетів. Найбільшими університетами є:

- Кельнський (60 тис. студентів);

- Мюнхенський (60 тис. студентів);

- Берлінський (45 тис. студентів).

Німці - одна $з$ найінформованіших націй світу. На 1 тис.жителів припадає 500 примірників газет і 600 телевізорів. 
ФРН належить до найбільших торговельних партнерів України.

Дискусія: Схарактеризуйте перспективу співробітництва Німеччини й України в галузі науковомісткого машинобудування.

\section{ФРАНЦІЯ}

Франція володіє багатовіковою культурною спадщиною.

У списку ЮНЕСКО - 22 об'єкти (монастирі, собори, палаци й парки, давньоримські пам'ятки).

Достатньо розвинена освітня сфера; обов'язковою є 10-річна освіта. На 100 тис. осіб припадає понад 5 тис. студентів, які навчаються більш як у 400 вищих навчальних закладах.

Всесвітньо відома паризька Сорбонна, де навчається понад 100 тис. студентів.

Французькі газети і журнали «Монд», «Фігаро», «Парі-матч» відомі далеко за межами країни.

Дискусія: Схарактеризуйте перспективу співробітництва Франції й україни в галузі харчової промисловості (перше місце в Європі); парфумерно-фармацевтичної промисловості.

\section{ВЕЛИКА БРИТАНІЯ}

Унесок британців у світову цивілізацію важливий.

Високий культурний культурний рівень населення забезпечується в тому числі досконалою освітньою системою.

Обов'язковою є 11-річна освіта. На 100 тис. осіб припадає 2170 студентів. Майже 33\% загальних громадських видатків йдуть на потреби цієї сфери.

У країні безліч музеїв, бібліотек, театрів і концертних залів. Серед них всесвітньо відомий Британський музей, Шекспірівський театр тощо.

У списку ЮНЕСКО - 16 обєктів. Найстарішими є Оксфордський (1167р.) i Кембриджський (1209р.) університети.

Британці належать до націй, які найбільше читають. За опитуваннями $65 \%$ читають центральні газети і 90\% - місцеві.

Освіта й охорона здоров'я - безкоштовні.

Дискусія: Схарактеризуйте перспективи співробітництва в освітній галузі між Великою Британією й Україною.

\section{ІТАЛІЯ}

Італія має давню і значну спадщину, яка бере свій початок від етрусків і римлян. Історикокультурна спадщина Стародавнього Риму й епохи Відродження найбільша у світі.

Болонський університет найстаріший у Європі.

У списку ЮНЕСКО - 19 об'єктів. Архітектурні пам'ятники, скульптури, музеї, театри мають світове значення.

Обов'язковою є восьмирічна освіта. На 100 тис. осіб припадає 2795 студентів.

Італія посідає провідне місце у світі за кількістю лікарів та витратами на освіту й охорону здоров'я. Італії належить перше місце в Європі за кількістю місць у готелях.

Провідні італійські газети відомі за ії межами: «Республіка», «Стампа», «Корр’єре делла сера».

Зовнішньоторговельний оборот між Італією та україною в останні роки досягав 800 млн. дол. США.

Дискусія: Схарактеризуйте перспективу економічних взаємовідносин між Італією i Україною в сільськогосподарській галузі (Італія займає перше місце у світі з вирощування оливок, шосте - цитрусових).

3. Навчально-пізнавальна компетентність - це сукупність компетенцій учня у сфері самостійної пізнавальної діяльності, до якої входять елементи логічної, методологічної, загальнонавчальної діяльності, що співвідноситься з реальними об'єктами пізнання: знаннями, вміннями цілепокладання, плануванням, аналізом, рефлексією, самооцінкою навчальнопізнавальної діяльності. Учень оволодіває креативними навичками продуктивної діяльності: добуванням знань безпосередньо з реальності, володінням прийомами дій у нестандартних ситуаціях, евристичними методами рішення проблем. У рамках цієї компетенції визначаються вимоги відповідної функціональної грамотності: вміння відрізняти факти від домислів, володіння вимірювальними навичками, використання імовірнісних, статистичних та інших методів пізнання.

4. Інформаційна компетентність, яка забезпечує навички діяльності учня з інформацією, що міститься в навчальних предметах та освітніх царинах, в оточуючому світі. За допомогою 
реальних об'єктів (телевізор, магнітофон, телефон, факс, комп'ютер, принтер, модем, копір) та інформаційних технологій (аудіо- та відеозапис, електронна пошта, ЗМІ, Інтернет) формуються вміння самостійно шукати, аналізувати та відбирати необхідну інформацію, організовувати, перетворювати, зберігати та передавати іiі.

5. Комунікативна компетентність - знання необхідних мовних ресурсів (володіння тезаурисним запасом географічної науки), засобів взаємодії з людьми і подіями безпосередньо й опосередковано; навички роботи в групі, володіння різними соціальними ролями в колективі.

6. Соціально-трудова компетентність - це володіння знанням і досвідом у громадянськосуспільній діяльності (виконання ролі громадянина, наглядача, представника, виборця тощо), в соціально-трудовій галузі (права споживача, покупця, клієнта, виробника), в сфері родинних відносин і обов'язків, у питаннях економіки та права, у професійному самовизначенні. До змісту цієї компетенції віднесено, наприклад, уміння аналізувати ситуацію на ринку праці, діяти відповідно до особистої й суспільної користі, володіти етикою трудових і громадянських взаємовідносин. Учень оволодіває мінімально необхідними для життя в сучасному суспільстві навичками соціальної активності та функціональної грамотності.

7. Компетентність особистісного вдосконалення спрямована на засвоєння засобів фізичного, духовного та інтелектуального саморозвитку, емоційну саморегуляцію та самопідтримання. Реальним об'єктом в цьому випадку є сам учень, який оволодіває способами діяльності у власних інтересах та можливостях, що виявляється в його безперервному самопізнанні, розвитку необхідних сучасній людині особистісних якостей, формуванні психологічної грамотності, культури мислення і поведінки.

Географічна компетентність учнів як форма практичного засвоєння результатів пізнання економічної діяльності, яка здобута завдяки навчанню й орієнтована на самостійну участь особистості в навчально-пізнавальному процесі, а також на успішне ії включення в трудову діяльність дозволяє розглядати ііі як систему: 1) знань, умінь і навичок розуміння законів географічної науки; 2) географічних знань, умінь $i$ навичок розуміння й інтерпретачї природних явищ і відношень між ними; 3) географічних знань, умінь і навичок роботи $з$ географічними поняттями.

Подана структура географічної компетентності в перспективі вимагає детального розгляду педагогічної категорії «географічні знання» в загальноосвітній системі в процесі навчання учнів географії та основ соціальної географії.

\section{Література}

1. Равен Дж. Педагогическое тестирование : Проблемы, заблуждения, перспективы / Джон Равен ; [пер. с англ.]. - [2-е изд., испр.]. - М. : «Когито-Центр», 2001. - 142 с. 2. Хуторской А. В. Ключевые компетенции как компонент личностно-ориентированной парадигмы / А. В. Хуторской // Народное образование. - 2003. - № 2. - С. 58-64.

\section{ФОРМУВАННЯ ОСНОВ ЕКОЛОГІЧНОЇ КУЛЬТУРИ УЧНІВ СЕРЕДНІХ КЛАСІВ У ПРОЦЕСІ ВИВЧЕННЯ ПРИРОДОЗНАВСТВА}

Хроленко М. В. Формування основ екологічної культури учнів середніх класів у процесі вивчення природознавства.

Стаття присвячена актуальній проблемі формування екологічної культури учнів 5-го класу засобами дидактичної гри. У статті розкрито значення екологічних дидактичних ігор у формуванні екокультури особистості, розроблено критерії добору навчального екологічного матеріалу, запропоновано типологію таких ігор та наведені приклади їх використання.

Ключові слова: екологічне виховання, екологічна культура, ігрова діяльність, екологічна дидактична гра.

Хроленко М. В. Формирование основ экологической культуры учеников средних классов в процессе изучения природоведения.

Статья посвящена актуальной проблеме формирования экологической культуры учащихся 5-го класса средствами дидактической игры. В статье раскрыто значение экологических 